\title{
Setting priorities for private land conservation in fire-prone landscapes: Are fire risk reduction and biodiversity conservation competing or compatible objectives?
}

\author{
$\underline{\text { Alexandra D. Syphard }}^{1}, \underline{\text { Van Butsic }}^{2}, \underline{\text { Avi Bar-Massada }}^{3}, \underline{\text { Jon E. Keelev }}^{4}, \underline{\text { Jeff A. Tracev }}^{5}$ and Robert N. Fisher $^{5}$
}

\begin{abstract}
Although wildfire plays an important role in maintaining biodiversity in many ecosystems, fire management to protect human assets is often carried out by different agencies than those tasked for conserving biodiversity. In fact, fire risk reduction and biodiversity conservation are often viewed as competing objectives. Here we explored the role of management through private land conservation and asked whether we could identify private land acquisition strategies that fulfill the mutual objectives of biodiversity conservation and fire risk reduction, or whether the maximization of one objective comes at a detriment to the other. Using a fixed budget and number of homes slated for development, we simulated 20 years of housing growth under alternative conservation selection strategies, and then projected the mean risk of fires destroying structures and the area and configuration of important habitat types in San Diego County, California, USA. We found clear differences in both fire risk projections and biodiversity impacts based on the way conservation lands are prioritized for selection, but these differences were split between two distinct groupings. If no conservation lands were purchased, or if purchases were prioritized based on cost or likelihood of development, both the projected fire risk and biodiversity impacts were much higher than if conservation lands were purchased in areas with high fire hazard or high species richness. Thus, conserving land focused on either of the two objectives resulted in nearly equivalent mutual benefits for both. These benefits not only resulted from preventing development in sensitive areas, but they were also due to the different housing patterns and arrangements that occurred as development was displaced from those areas. Although biodiversity conflicts may still arise using other fire management strategies, this study shows that mutual objectives can be attained through land-use planning in this region. These results likely generalize to any place where high species richness overlaps with hazardous wildland vegetation.
\end{abstract}

Key Words: housing arrangement; reserve design; site selection; southern California; species richness; wildfire

\section{INTRODUCTION}

In many ecosystems around the world, wildfire is an important natural process that has shaped the evolution of species and helps to maintain biodiversity (Bond and Keeley 2005, Keeley et al. 2011). At the same time, fire can also be an ecosystem threat if the disturbance regime is altered beyond its historical range of variability (Folke et al. 2004). Additionally, on many contemporary landscapes, fire has become a pervasive threat to human lives and property, resulting in a growing urgency to find management solutions that will minimize fire impact on human assets (Gill et al. 2013). Despite the interconnectedness of these effects, the role of fire in biodiversity conservation and as a hazard to human welfare, are often viewed as separate problems, and in many cases as competing objectives (Morrison et al. 1996, Driscoll et al. 2010, 2016), and are often managed by different agencies (Driscoll et al. 2010).

In reality, the extent to which fire risk reduction and biodiversity conservation are compatible or not depends largely on the fire management strategy under consideration and the ecological context of the region at hand (Moritz et al. 2014). Not only does the natural role of fire vary across ecosystems, but the way in which humans have altered fire regimes and the extent to which they are threatened by fire, also varies. Furthermore, certain management actions may have differential ecological impacts in different ecosystems. For example, the most common and widely advocated strategy for fire risk reduction has been to reduce hazardous fuels, either through mechanical removal or by prescription burning (Agee and Skinner 2005). Depending on the geographical context, these fuel treatments may either facilitate biodiversity conservation or be a threat to it. In certain dry or fire-prone mesic forests, prescribed fires or mechanical fuel reduction to thin understory vegetation may not only reduce fire hazard to humans, but can increase the resilience of the forest and protect biodiversity by reducing the potential for uncharacteristically high-severity crown fires (Stephens et al. 2012).

On the other hand, fuels management in nonforested ecosystems, and even in some forested systems, often results in negative ecological impacts such as the direct conversion of native woody plant cover to weedy grasslands, providing corridors for invasion of non-native species, or altering hydrological regimes (Keeley et al. 2009). It is here where conflicts between biodiversity conservation and asset protection tend to arise, and fuels reduction to protect communities is best considered as a resource sacrifice. A range of decision-making tools have been proposed to help evaluate and minimize trade-offs among these kinds of competing management objectives, particularly with regards to fuels management and biodiversity (Ohlson et al. 2006, Driscoll et al. 2010, Conlisk et al. 2015).

An alternative to fuels management for fire risk reduction that is gaining attention is land-use decision making. Studies are beginning to show that altering the arrangement and location of new housing developments may provide significantly different

${ }^{1}$ Conservation Biology Institute, ${ }^{2}$ Department of Environmental Science, Policy and Management, University of California Berkeley, ${ }^{3}$ Department of Biology and Environment, University of Haifa at Oranim, ${ }^{4}$ U.S. Geological Survey, Western Ecological Research Center, Sequoia-Kings Canyon Field Station, Three Rivers, California, ${ }^{5}$ Western Ecological Research Center, U.S. Geological Survey, San Diego Field Station, San Diego, California 
outcomes in terms of fire risk to homes (Bhandary and Muller 2009, Buxton et al. 2011, Syphard et al. 2013). In fact, the location and arrangement of homes in some locations may be the most influential factor in determining whether these homes are destroyed in a fire (Syphard et al. 2012, Alexandre et al. 2016). On the other hand, "smart growth" is a form of land-use planning that focuses specifically on the objective of balancing growth with conservation of biodiversity (Underwood et al. 2011), and there have been calls for the integration of land preservation into a comprehensive land-use planning approach (Daniels and Lapping 2005). Despite evidence that land-use decision making can both affect fire risk and biodiversity, little attention has been focused on strategies to meet both objectives.

Land-use decision making can occur through two primary vehicles. The first is the most commonly considered form of planning, which is the regulatory approach to zoning and housing density of new construction, and this approach has been shown to alter projections of fire risk (Syphard et al. 2013). The other way to affect development patterns is through the purchase of conservation land that restricts development in that area, and this approach is often intertwined with the regulatory approach in terms of impact and execution (Gerber and Rissman 2012). Nevertheless, the primary goal of private land purchase and acquisition has been to preserve ecologically sensitive or biologically diverse areas; in fact, the design of reserve networks is the cornerstone of the conservation planning literature (Margules and Pressey 2000).

How to select land for conservation in a way that best preserves biodiversity has been a source of debate and study in the conservation biology literature for decades (e.g., Margules et al. 1982, Cabeza and Moilanen 2001). The most common approaches include focusing on the lands' biological value, economic cost, and likelihood of development (Newburn et al. 2005, Wilson et al. 2006, Carwardine et al. 2008). Despite this focus on selection strategies for biological conservation, a recent study shows that targeting high fire-hazard areas for private land acquisition could effectively reduce the projected fire risk to homes, particularly when compared to other strategies focused on cost and likelihood of development (Butsic et al. 2016). Nevertheless, that study only considered the impacts of selection strategy on fire risk without considering biodiversity implications.

We expand upon that research and ask whether we can identify conservation selection strategies that fulfill the mutual objectives of biodiversity conservation and fire risk reduction, or whether the maximization of one objective comes at a detriment to the other. Using a fixed conservation budget and set number of homes slated for development, we simulated 20 years of housing growth under alternative reserve selection strategies. For each scenario simulated, we projected the mean risk of fires destroying structures as well as the area and configuration of important habitat types in San Diego County, California, USA. Two of the selection strategies focused exclusively on either cost efficiency or likelihood of development, and we compared these to a range of strategies focused on targeting lands designated as high fire hazard, high species richness, or both. Using this modeling framework we asked the following:

1. Which selection strategies result in the lowest projected fire risk or conserve the most ecologically important habitat?
2. Are there strategies that can maximize the outcome for both of the objectives, or does meeting one objective come at the expense of the other?

3. How do general strategies focused on cost efficiency and development potential compare to strategies focused on selecting specific geographical areas to target for purchase?

\section{METHODS}

\section{Study area}

Our study area (Fig. 1a) included the $8312 \mathrm{~km}^{2}$ of land encompassed by the South Coast Ecoregion (Miles and Goudey 1997) portion of San Diego County. With a Mediterranean climate, the region experiences cool, wet winters and hot, dry summers, and the environmental heterogeneity of the region contributes to its high level of biodiversity (http://www.bonap. org/diversity/diversity/diversity.html). In addition, this biodiversity hotspot has more threatened and endangered species than any other county in the continental U.S. (Regan et al. 2008). Most native plant communities (Fig. 1b) are resilient to the region's natural fire regime of periodic, stand-replacing crown fires, the largest of which typically occur during annual autumn Santa Ana wind events (Keeley and Davis 2007, Moritz et al. 2010). Nevertheless, fire activity has increased substantially in recent decades because of human-caused ignitions associated with rapid population growth and urban expansion (Keeley et al. 1999, Syphard et al. 2007a, Safford et al. 2011). Consequently, the intervals between fires in the region are substantially shorter than the historical norm (Safford and van de Water 2014), and often too short relative to the time required by most shrubland species to recover after fire. Where fire return intervals are shorter than 10 to 20 years, native shrublands are often vulnerable to extirpation and replacement with more fire-prone weedy grasslands (Keeley and Brennan 2012, Lippitt et al. 2012). Recent large fire events have also resulted in thousands of homes destroyed and many lives lost (Syphard et al. 2012).

Humans are responsible for most of the fire ignitions and often at the worst times of the year (Syphard and Keeley 2015). Concomitant with population growth has been the expansion of urban development, resulting in massive habitat loss and fragmentation. In recognition of these threats to the region's biodiversity, federal, state, and local governments and members of the Land Trust Alliance have been actively involved in conservation planning and private land acquisition (Pollak 2001, Land Trust Alliance 2015, San Diego County 2015). In fact, approximately $45 \%$ of the nonurbanized land in the county has been conserved, particularly in the eastern part of the county (in some areas outside of our study area boundary). Nevertheless, housing growth and urban expansion is predicted to continue with more than one million new residents expected by 2030 (Messner et al. 2011).

\section{Modeling framework overview}

To evaluate the potential effect of conservation selection strategy on fire risk and biodiversity, we integrated previously developed econometric and land development models (Syphard et al. 2013, Butsic et al. 2016) with a fire risk model (Syphard et al. 2012, 2013) to project alternative scenarios of conservation purchase and housing growth over a 20 -year period. We used a fixed conservation budget (US\$40 million annually) and fixed number of dwelling units (37,000 per five-year time step) to allocate across 
Fig. 1. Maps of (a) study area, (b) major vegetation types, and priority conservation areas for (c) reducing fire hazard, and (d) maximizing species richness.
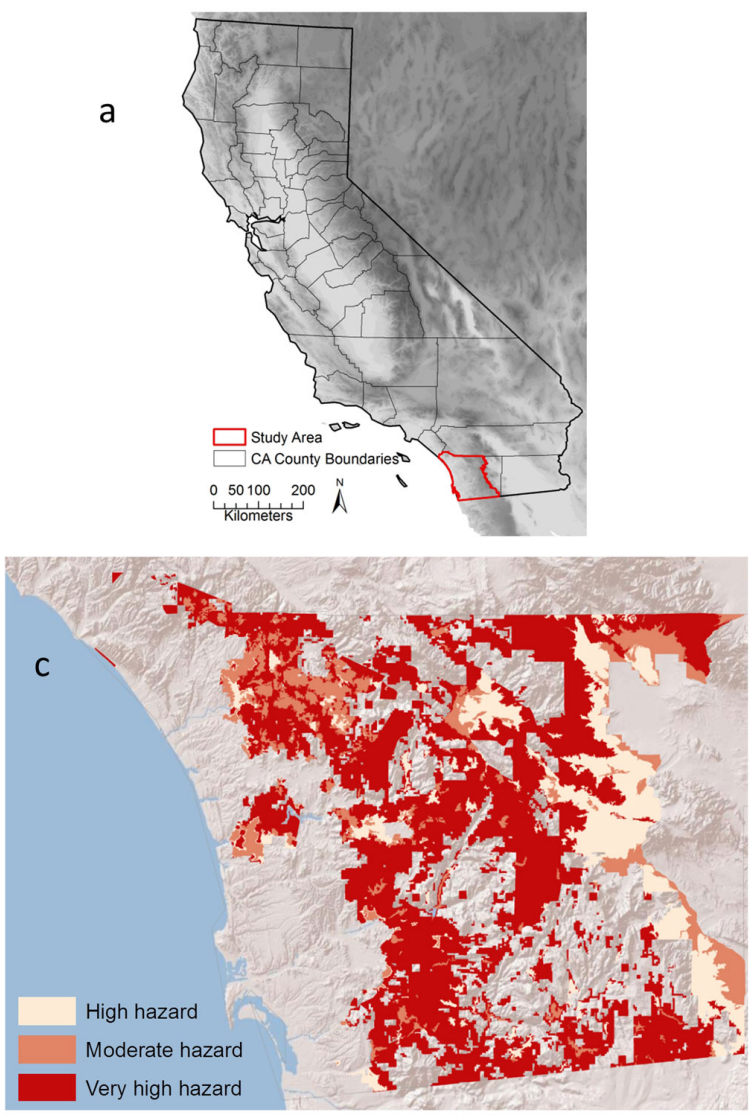
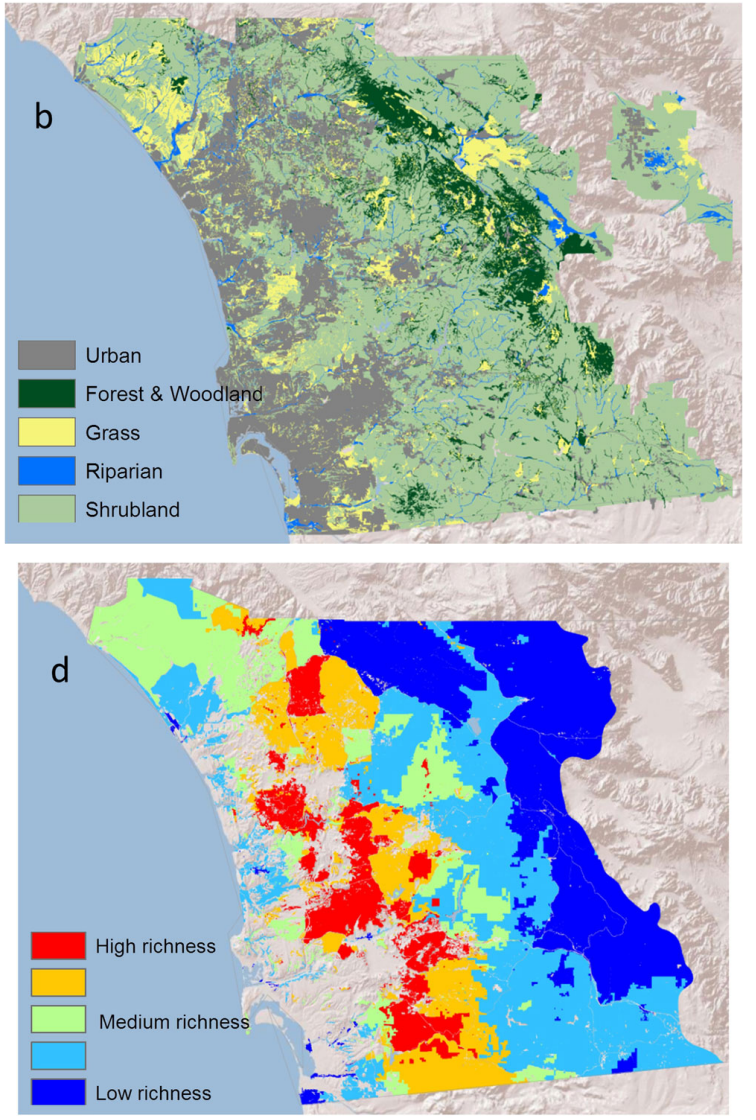

the landscape; thus, the only thing that varied among scenarios was the location and amount of conservation land selected. We established this budget based on past spending on private land in San Diego County, and the number of new dwellings is based on growth estimates by the San Diego Association of Governments (SANDAG), the regional planning agency (San Diego County 2011). The estimate for the fixed number of dwelling units was based on the regional planning agency's projected estimate of growth to 2030. Any parcels purchased for conservation in one time step were restricted from development in subsequent time steps. After every time step for every scenario, we estimated mean fire risk across all structures (existing and new development) and calculated the area and pattern of undeveloped land as a surrogate for biodiversity. Our approach for ranking fire hazard and biodiversity value in the econometric model, as well as our methods for assessing fire risk and biodiversity outcomes is described below.

\section{Econometric land development model}

We simulated different scenarios of housing growth based on a random effects probit econometric model that predicted the probability of parcel subdivision in five-year time steps (see Syphard et al. 2013, Butsic et al. 2016). The model was conditioned on actual subdivision of county parcels from 2004 - 2010 and 2010 - 2014. We used this 10-year time period because it covered a range of both boom and busts development. Thus, the dependent variable was binary, whether or not a subdivision occurred historically, and the predictor variables included a range of factors shown to impact land owner decisions to subdivide in similar settings (Irwin et al. 2009, Carrión-Flores and Irwin 2010), including the following: lot size, zoning type, municipality identification variables, elevation and slope of parcel, distance from the ocean, nearest sewer line, freeways, public park, floodplain, and nearest lake. These predictor variables are described in Syphard et al. (2013). Output from the model was the predicted probabilities of conversion for each parcel in our dataset.

\section{Fire risk rankings}

Fire hazard rankings were derived from fire hazard severity zone maps developed by the California Department of Forestry and Fire Protection (http://www.fire.ca.gov/). These maps rank potential fire behavior and associated likelihood of damage based on potential vegetation (fuels), topography, weather, and ember production. We normalized values such that those areas classified as urban and thus nonburnable were ranked 0 ; areas with moderate fire hazard 1; high fire hazard 2; and very high fire hazard 3 (Fig. 1c, Table 1).

\section{Biodiversity rankings}

To rank biodiversity across the landscape, we used a map that will also be used operationally in San Diego County to prioritize land 
Table 1. Description of conservation selection algorithms. Selection algorithms for conserving parcels. $\mathrm{C}$ is equal to the cost of conservation; ha is equal to the size of the parcel; $\mathrm{T}$ is equal to the transition probability of the parcel; $\mathrm{F}$ is equal to the fire hazard of the parcel (higher values for higher hazard); B is equal to the species richness score (low values correspond to richness rankings).

\begin{tabular}{|c|c|c|c|}
\hline & Formula & Ranking & Intuition \\
\hline SubMax & $\mathrm{T}$ & High to low & $\begin{array}{l}\text { Acquire parcels that will develop in the absence of } \\
\text { conservation }\end{array}$ \\
\hline CostMin & $\mathrm{C} / \mathrm{ha}$ & Low to high & Acquire as much property as possible at the least cost \\
\hline FireMin & $(\mathrm{C} / \mathrm{ha}) / \mathrm{F}$ & Low to high & Acquire inexpensive parcels with high fire hazard \\
\hline FireMinMax & $((C / h a) / F) / T$ & Low to high & $\begin{array}{l}\text { Acquire parcels that are inexpensive, likely to subdivide, and } \\
\text { have high fire hazard }\end{array}$ \\
\hline BioMax & $(C / h a)^{*} B$ & Low to high & $\begin{array}{l}\text { Acquire parcels that are inexpensive with high species } \\
\text { richness }\end{array}$ \\
\hline BioMaxMin & $(C / h a) * B / T$ & Low to high & $\begin{array}{l}\text { Acquire parcels that are inexpensive, species rich, and are } \\
\text { likely to subdivide }\end{array}$ \\
\hline BioMaxFire & $(C / h a)^{*} B / F$ & Low to high & $\begin{array}{l}\text { Acquire parcels that are inexpensive, species rich, and have } \\
\text { high fire hazard }\end{array}$ \\
\hline BioMaxMinFire & $(C / h a) * B / T / F$ & Low to high & $\begin{array}{l}\text { Acquire parcels that are inexpensive, species rich, have high } \\
\text { fire hazard, and are likely to subdivide }\end{array}$ \\
\hline
\end{tabular}

for conservation acquisition. The map was created using a Pareto ranking algorithm (Moilanen et al. 2009; J. A. Tracey, C. J. Rochester, S. A. Hathaway, C. Brehme, K. Preston, A. D. Syphard, A. Vandergast, J. Diffendorfer, J. Franklin, J. McKenzie, S. Morrison, G. Nichols, T. Oberbauer, W. D. Spencer, S. Tremor, C. Winchell, and R. N. Fisher, unpublished manuscript) to prioritize spatial units (patches, mean size $=94.2$ ha) based on predicted species richness of plants, herpetofauna (amphibians and reptiles), and mammals (J. A. Tracey, C. J. Rochester, S. A. Hathaway, C. Brehme, K. Preston, A. D. Syphard, A. Vandergast, J. Diffendorfer, J. Franklin, J. McKenzie, S. Morrison, G. Nichols, T. Oberbauer, W. D. Spencer, S. Tremor, C. Winchell, and R. N. Fisher, unpublished manuscript). First, we constructed a grid of 50-meter cells that covered San Diego County. We excluded grid cells that were dominated by urban land use or water, e.g. reservoirs, or intersected by major roads. We then grouped the remaining grid cells into patches of contiguous grid cells. Second, for each taxonomic group, the predicted species richness grid (at the same resolution and extent of the grid used to create the patches) was developed by summing grids of predicted species occurrence for individual species within that group. We used predicted occurrence for 138 species of plants (Principe et al. 2013), 29 species of reptiles and amphibians (Franklin et al. 2009), and 18 species of mammals (J. E. Diffendorfer, S. Tremor, W. S. Spencer, 2006, unpublished data). The predicted species richness for each of the three groups was then averaged within each patch, resulting in three species richness criteria per patch. Finally, using the Pareto ranking algorithm (J. A. Tracey, C. J. Rochester, S. A. Hathaway, C. Brehme, K. Preston, A. D. Syphard, A. Vandergast, J. Diffendorfer, J. Franklin, J. McKenzie, S. Morrison, G. Nichols, T. Oberbauer, W. D. Spencer, S. Tremor, C. Winchell, and R. N. Fisher, unpublished manuscript), the patches were then ranked using these patch criteria resulting in the final map of biodiversity ranks.

\section{Conservation selection algorithms}

To select which parcels would be conserved in each time step, we used eight different selection algorithms (Table 1), in addition to a scenario of no conservation. The first algorithm CostMin, simply selected the parcels with the lowest cost per ha, based the assessed value of a parcel as recorded by San Diego County.
Second, SubMax, acquired parcels that were most likely to subdivide, based on predicted probabilities from the econometric model. The FireMin model was similar to the CostMin algorithm, but also minimized fire risk. FireMinMax accounted for fire risk, cost, and subdivision probability. BioMax maximized biodiversity while minimizing cost, and BioMaxMin did the same but also included information on the likelihood of subdivision. Finally, FireBioMin and FireBioMinMax reintroduced the fire rankings into the biodiversity algorithms.

To understand the relative impact of the different selection strategies on fire risk and biodiversity, we ran land development simulations to place new structures on landscape as a function of each algorithm. Beginning with an initial map of undeveloped parcels in each time step, we first used the econometric model to predict the likelihood of each parcel subdividing. For these same parcels, we also used assessor data to calculate their purchase price. Then, using a budget of $\$ 40$ million per year, and the given algorithm, we selected parcels for conservation acquisition until the budget was completely allocated. Any left-over budget was transferred to the next time period.

With the new conservation lands restricted from development, we then allocated a fixed number of new structures across the landscape in undeveloped parcels that were identified as suitable for subdivision. Those parcels with the highest probability of subdivision ranked first for development. We therefore subdivided parcels and allocated structures to them according to these rankings until we placed 37,000 new structures on the map for each time step. The number of structures to allocate to the newly subdivided parcels was determined based on the parcels' zoning and we assumed that parcels developed at the highest density allowed by law. These steps repeated every five years for 20 years.

\section{Quantifying fire risk to structures}

We estimated the mean fire risk to structures by deriving several gridded maps from the output of the housing development scenarios and using them as input to a fire risk model (described in Butsic et al. 2016). We developed the fire risk model using MaxEnt (Phillips et al. 2006, Elith et al. 2011), which is a mapbased software package that, although originally designed for 
species distribution modeling, has also been effective for modeling fire probability (e.g., Bar-Massada et al. 2012, Moritz et al. 2012) and risk to structures (Syphard et al. 2012, 2013). MaxEnt uses a machine-learning algorithm to predict spatial distributions by iteratively contrasting values of point-based distribution data of the dependent variable to values derived from a large random sample of background points for all mapped explanatory variables. The output is an exponential function that assigns a fire risk probability to each cell in a map.

Here, the dependent variable was the location of structures destroyed by wildfire between 2001 and 2010, and the explanatory variables included biophysical factors such as terrain and fuel type as well as distance to roads and a range of maps delineating housing pattern and location (described in Syphard et al. 2012, 2013). The three maps that we calculated for all conservation scenarios included the following: structure density, Euclidean distance to nearest structure, and size of housing cluster, all of which were found to be important in explaining structure destruction (Syphard et al. 2012). For each time step of each scenario, we ran MaxEnt for five cross-validated replicates using the same settings as in Syphard et al. (2012, 2013), which estimated the model using hinge, linear, and quadratic features and a regularization setting of 2.5 to reduce model overfitting. For all structure locations in the housing maps created for the scenarios, we extracted the mean probabilities of fire risk that were output from the MaxEnt model replicates, and then averaged them across the landscape for comparison.

\section{Assessing biological impact}

Because we used species richness rankings as a basis for selecting conservation lands, we chose a different set of metrics to quantify and compare potential biological impacts. For all scenarios, we considered the development footprint as the land within a $100 \mathrm{~m}$ circumference of structures, allowing for the inclusion of areas immediately adjacent to structures that are typically characterized by urban landscaping rather than natural vegetation. Therefore, we created binary maps in which the area within overlapping buffers of structures was classified as developed, and all other land was classified as habitat. We then overlaid these maps on a vegetation type map for San Diego County (Oberbauer et al. 2012) and quantified the total area of undeveloped land that overlapped with the region's most extensive vegetation types (Fig. 1b), shrubland, riparian, and wetland, and forest and woodlands, which are primarily native, along with "grassland," which is primarily non-native.

We also calculated three simple landscape metrics, total core habitat area, edge density, and number of distinct core areas, on the undeveloped parts of the landscape using FRAGSTATSv4 (McGarigal et al. 2012). These metrics have long been recognized for their association with a myriad of ecological processes and have been widely used and advocated as tools for comparing different landscapes over time (Turner 1989, Gustafson 1998). For calculating core area and number of distinct core patches, we used a small 5-m offset from patch boundaries to restrict the inclusion of "edge habitat," which may reflect lower habitat quality. Edge between habitat and urban areas may affect a number of ecological processes such as migration and dispersal, and may alter the structure and function of vegetation and species' habitat preferences (Turner 1989, McGarigal et al. 2012). In summary, landscapes with larger total areas of habitat; with fewer, larger habitat patches; and with lower edge density, are likely to reflect higher ecological integrity, and thus may support more biodiversity (Fig. 1d).

\section{RESULTS}

Across the 20-year simulation period, the projected mean fire risk to structures, i.e., the probability of a house being destroyed, varied over time and among scenarios (Fig. 2). Under the SubMax algorithm and with no conservation, fire risk increased sharply during the first time step, declined as development started to fill in, then increased again with more housing expansion. These two scenarios resulted in the most dispersed pattern of housing, and the one located farthest east (Fig. 3). The CostMin algorithm resulted in the third most dispersed housing pattern, which was located farther east than the remaining scenarios (Fig. 3). CostMin was among the top three scenarios for projected fire risk (Fig. 2). At the end of the simulation, the SubMax algorithm resulted in the single highest fire risk.

Fig. 2. Mean projected fire risk to simulated structures across conservation strategies over time. Risk is defined as the probability of a structure being destroyed in a fire.

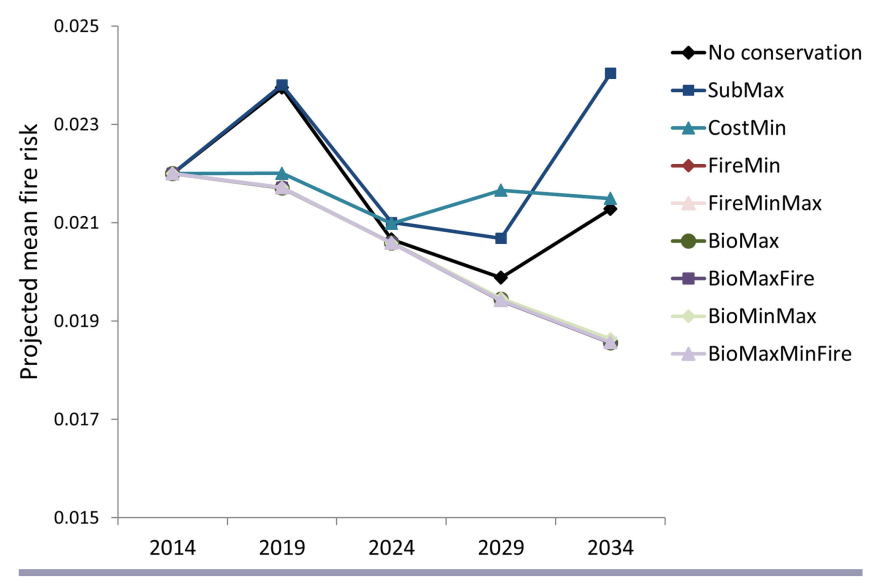

Fig. 3. Map illustrating newly developed structures in year 2034 for all conservation selection scenarios.

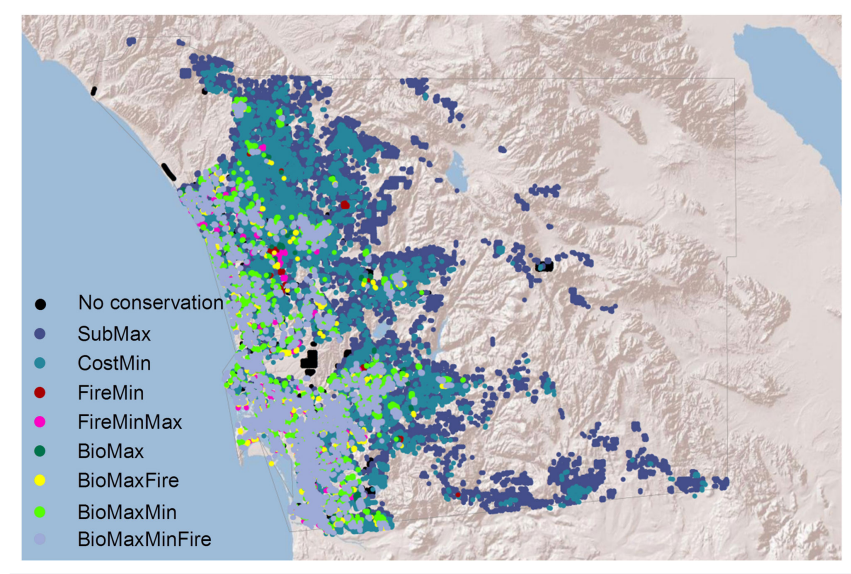


Fig. 4. Area of major vegetation types, including (a) shrubland, (b) forest and woodland, (c) riparian and wetland, and (d) grassland over time for all conservation selection scenarios.
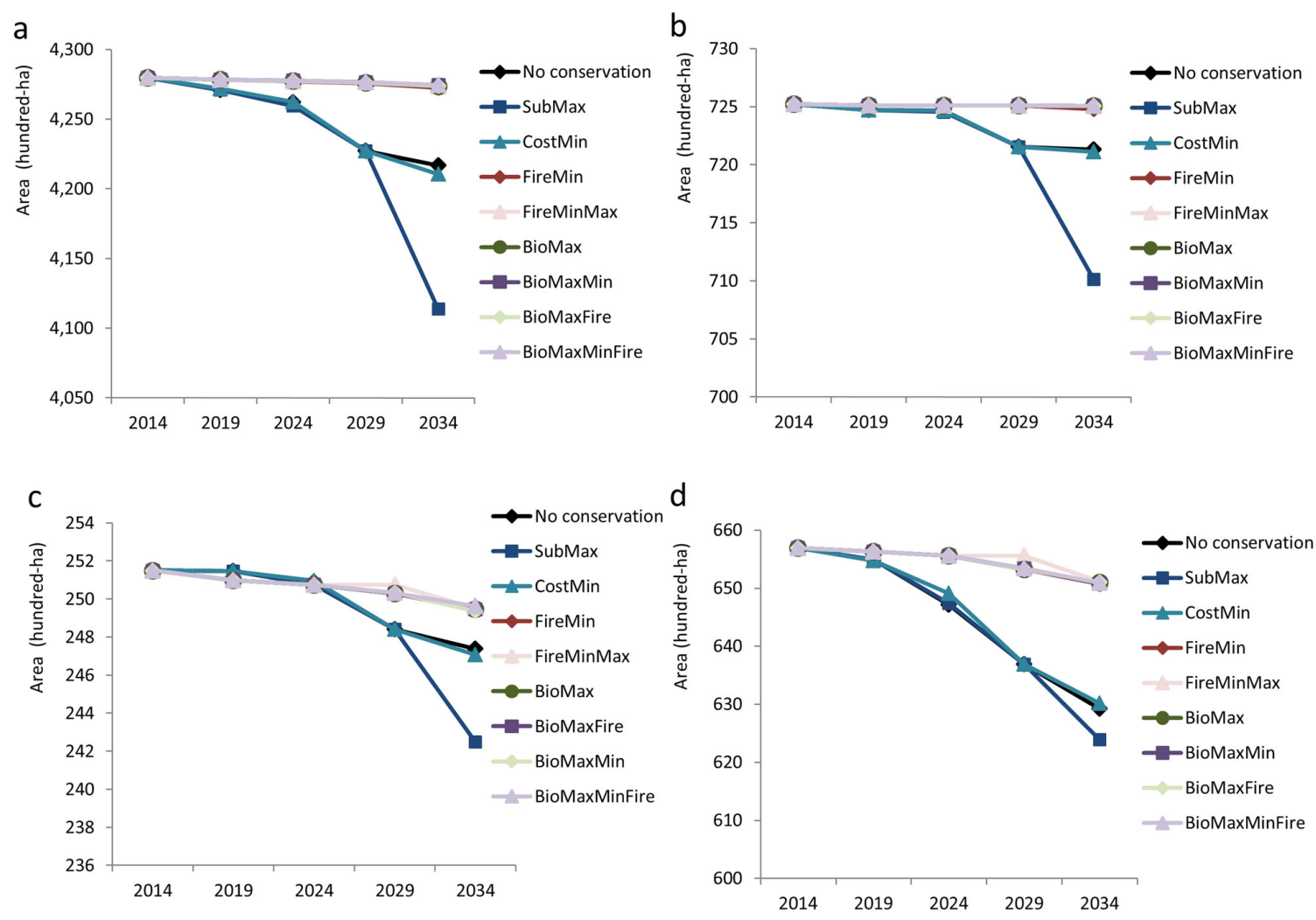

In contrast to the algorithms focused on cost and development likelihood, or no conservation, the selection strategies prioritizing fire hazard and biodiversity, and all combinations thereof, resulted in a progressively lowering of projected mean fire risk over time without any oscillations (Fig. 2). Most of the housing development in these scenarios occurred closer to the coast (Fig. 3). Differences among all these scenarios were negligible.

Trends in vegetation loss over time were similar in terms of rankings among scenarios across all four vegetation types (Fig. 4 a-d), with the most substantial decline occurring under the SubMax algorithm, particularly from year 2029 to 2034. Along with SubMax, the CostMin and no conservation scenarios also resulted in substantial declines in vegetation over time compared to the rest of the scenarios, which were those prioritizing fire hazard and biodiversity. All combinations of fire hazard and biodiversity scenarios were, as with fire risk, strikingly similar to one another. The division between the groups of scenarios became more pronounced over time for all vegetation types and was most pronounced in shrubland (Fig. 4a) and grassland (Fig. 4d) because these were the two vegetation types that were most extensively developed by the SubMax, CostMin, and no conservation scenarios. Although vegetation loss in general was much lower in the fire and biodiversity scenarios, most of the decline occurred in riparian and wetland and grassland areas.

The trends in vegetation decline were mimicked in the calculation of total core habitat loss among scenarios (Fig. 5a). Again, the most habitat loss occurred when using the SubMax selection algorithm, and there was slightly more habitat loss using CostMin when compared to no conservation. The fire hazard and biodiversity scenarios all resulted in a similar slow decline in habitat area. The larger habitat loss in SubMax, CostMin, and no conservation was accompanied by a larger amount of habitat fragmentation, as seen through the increase in edge density (Fig. 5b) and number of distinct core patches (Fig. 5c), although there were even more habitat patches created using the CostMin algorithm than with no conservation. The habitat was fragmented into a slightly larger number of patches when using the fire hazard and biodiversity selection algorithms (Fig. 5c), but this introduced very little additional edge into the landscape (Fig. 5b).

\section{DISCUSSION}

Our simulations show clear differences in both fire risk projections and biodiversity impacts based on the way conservation lands are prioritized for selection. However, these differences are only apparent among scenarios focused either on cost efficiency or development likelihood, or with no conservation at all. In contrast, there are very negligible differences in either projected fire risk or habitat metrics under any combination of the fire hazard reduction or biodiversity conservation selection strategies. It is this group of strategies that resulted in the best outcome for both fire risk and biodiversity objectives. In other words, conserving land focused on either of those two objectives results in nearly equivalent mutual benefits for both. And those benefits 
Fig. 5. Landscape pattern metrics calculated for undeveloped land in all selection scenarios, including (a) area of core habitat, (b) edge density, and (c) number of distinct core patches.
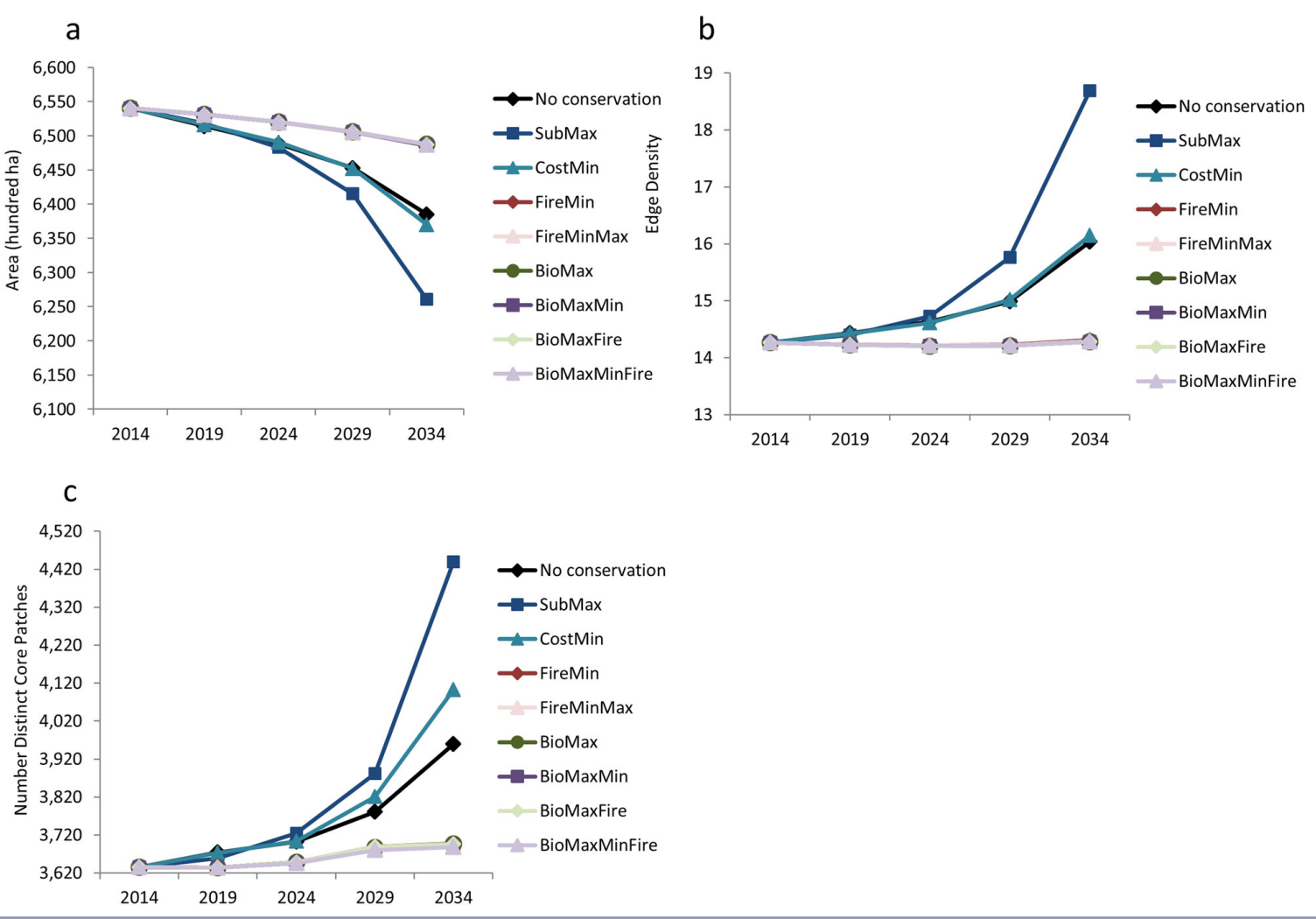

stand in contrast to strategies of just focusing on purchasing maximum land area or areas most likely to subdivide. Thus, it is important in our region to concentrate on the location of conservation lands more than just the cost or threat of development. Furthermore, developing in a way that reduces fire risk can have mutual benefits for conservation and vice versa.

One reason for the mutual benefits of prioritizing selection by location may be related to the areas where there is a geographical overlap in fire hazard and species richness (J. A. Tracey, C. J. Rochester, S. A. Hathaway, C. Brehme, K. Preston, A. D. Syphard, A. Vandergast, J. Diffendorfer, J. Franklin, J. McKenzie, S. Morrison, G. Nichols, T. Oberbauer, W. D. Spencer, S. Tremor, C. Winchell, and R. N. Fisher, unpublished manuscript). Although there is not a complete correspondence between these two maps, particularly in the eastern part of the landscape, those areas that do overlap occur in places that would otherwise have a good chance of developing. Therefore, private land acquisition in those areas has a good chance of precluding development where it would otherwise likely occur, and where it did occur in the other scenarios. In those scenarios, development in these overlapping areas not only occurred in the most hazardous locations, but it also impacted those areas with the highest species richness.

Substantial evidence has shown a significant, widespread spatial correlation between areas of high species richness and areas of high human population density, although the reasons why are complex (Luck 2007). Thus, our results may generalize across a range of regions because protecting land in areas of high species richness should preclude development in areas that are highly desirable for human habitation. For example, Fattorini and Strona (2016) found that areas most hospitable for species richness were positively related to human population density on Italian islands, suggesting that restricting species-rich areas from development may be critical for conserving biodiversity.

In addition to species-rich areas being more favorable for human development, these areas may also generally be the most fireprone. This is because biodiversity and productivity tend to be positively correlated (Naeem et al. 1996, Costanza et al. 2007). For example, studies in Australia show that, with some exceptions, the largest number of wildlife species occur within mid-to-late successional vegetation as opposed to areas with lower biomass, and the best strategy for conserving species richness is to minimize extensive wildfires (Taylor et al. 2013, Giljohann et al. 2015). Nevertheless, in most fire-prone ecosystems, productivity and biomass accumulation, i.e., fuel, are key indicators of high fire hazard (Pyne et al. 1996). This relationship is evident in the recent trend of agricultural abandonment and increasing fire hazard across southern Europe. In fact, much of this increasing fire hazard is likely going to occur close to human settlements (Viedma et al. 2015), which suggests that the findings in this study may be directly applicable in those regions.

In addition to the spatial congruence of species richness, development probability, and fire hazard, another geographical 
explanation for our results is the way recently purchased conservation land displaced subsequent development into different locations and densities. Because we allocated a fixed set of structures to build across all scenarios, these buildings had to be placed somewhere on the landscape in every simulation. As a result of private land acquisition in different quantities and locations, simulated development patterns evolved in response to the location of available developable land, relative to the cost and subdivision potential of those lands.

Our models assume development continues at a constant rate and under unchanging zoning and urban policy. If one were to relax these assumptions and allow for changes in these institutions, we might see the impact of private lands conservation magnified or negated. In other studies in San Diego, it has been shown that changing development patterns of homes impacts fire risk. If zoning or urban policy lead to more compact landscapes, it is likely that fire risk would be reduced even more. Zoning and urban policies may also impact the price and transition probability of properties. Given these changes, which properties would be selected for conservation would also be impacted by changing zoning and urban policy. Exactly how the competing dynamics of changing development pressures and prices would play out on the landscape is unknown, but an area of exciting future research.

The parcels with the highest likelihood of subdividing were concentrated within existing development along the coast. Thus, when those lands were conserved under the SubMax scenario, the resulting development was displaced into the more rural inland areas, where species richness and fire hazard are both high and housing density tends to be lower. Although these areas were cheaper than most coastal areas, many of the parcels that had the biggest area for the cheapest price were nevertheless outside of this zone of overlapping high species richness and fire hazard. Thus, although better than the SubMax scenario, the CostMin algorithm nevertheless resulted in a substantial number of structures being placed in hazardous patterns and locations, particularly compared to the scenarios in which land in those areas was prioritized for conservation. When land in those areas was purchased in the biodiversity and fire hazard scenarios, new construction was therefore pushed back into the coastal region as higher density infill-type development.

Research shows that not only is fire risk associated with hazardous geographic locations, but it is also largely a function of the pattern and arrangement of structures on the landscape (Syphard et al. 2012). Fire frequency and area burned in Mediterranean and nonforested regions tend to be highest where population and housing densities are low-to-intermediate (Keeley 2005, Syphard et al. 2007a, 2009, Lampin-Maillet et al. 2011). In our study area, these are the same patterns where houses are most likely to be destroyed by fire (Syphard et al. 2012, Alexandre et al. 2016). In particular, structure loss is highest at low to intermediate densities, surrounded by wildland vegetation, and in small, isolated neighborhoods (Syphard et al. 2007a,b, 2009, Lampin-Maillet et al. 2011). Thus, the scenarios that forced new construction into the coastal areas as higher density infill reduced fire risk not only because houses were not allowed to develop in hazardous areas, but they were also forced to occur in safer arrangements. Although overall diversity benefits from this strategy, in San Diego County there are a lot of regional species that are endemic only to coastal regions and many currently now only persist in small "boutique reserves" in these coastal areas (Regan et al. 2008).

The benefits to biodiversity occurred in much the same way as the reduction in fire risk; that is, conserving land in species-rich areas not only protected those areas in particular, but also resulted in housing patterns that had a smaller overall footprint with reduced habitat edge and fragmentation. Although higher density development could result in larger local ecological impacts, most research suggests that clustered, high-density development patterns substantially reduce the overall impact of development on wildlife habitat (Odell et al. 2003) and that exurban, rural development may result in disproportionately high negative effects on biodiversity and ecological processes (Hansen et al. 2005, Bar-Massada et al. 2014). In our study area, the clustered, infill-type development that occurred under the fire hazard and biodiversity selection scenarios also resulted in lower edge and fragmentation, which have long been associated with biodiversity decline (Turner 1989, Fahrig 2003, McGarigal et al. 2012).

Because fire frequency tends to be highest when housing patterns are low to intermediate, a clustered development pattern in this landscape may provide additional indirect ecological benefits. In southern California, human-caused ignitions at the wildlandurban interface have increased fire frequency well beyond the historical baseline (Keeley 2006, Syphard et al. 2007a, Safford and Van de Water 2014), and many native shrublands cannot withstand repeated fires. Furthermore, when shrublands are extirpated by too much fire, they often are replaced with fire-prone exotic annual grasses that can withstand and even promote additional fire (Zedler et al. 1983, Keeley and Brennan 2012, Lippitt et al. 2012) and support lower species diversity (Rochester et al. 2010). Thus, not only could clustered development reduce the number of human-caused ignitions, but it could also protect biodiversity by preventing some expansion of exotic grasses that would likely accompany expanding exurban development.

In conclusion, in southern California the two objectives of biodiversity conservation and fire risk reduction appear to be highly compatible when the management strategy is private land acquisition for conservation and the priority is to purchase lands in high species-richness or high fire-hazard areas. As suggested previously, these results likely generalize to any similar fire-prone region because of the common overlap between species richness, development potential, and fire hazard. Other commonly used management strategies, particularly in the form of fuels reduction to reduce fire hazard, will likely continue to be a conflict in this and other nonforested ecosystems, despite their compatibility in some other locations, like the dry ponderosa pine forests in the western U.S. In the San Diego region, however, it may be important to consider different decision-support methods (e.g., Driscoll et al. 2016) to identify the most appropriate timing and location of fuels management to provide the largest benefit with the smallest ecological impact.

Responses to this article can be read online at: http://www.ecologyandsociety.org/issues/responses. $\mathrm{php} / 8410$ 


\section{Acknowledgments:}

We thank USGS Ecosystems Mission Area and the Wildfire Research Program for funding and project support. Any use of trade, product, or firm names is for descriptive purposes only and does not imply endorsement by the U.S. Government.

\section{LITERATURE CITED}

Agee, J. K., and C. N. Skinner. 2005. Basic principles of forest fuel reduction treatments. Forest Ecology and Management 211:83-96. http://dx.doi.org/10.1016/j.foreco.2005.01.034

Alexandre, P. M., S. I. Stewart, M. H. Mockrin, N. S. Keuler, A. D. Syphard, A. Bar-Massada, M. K. Clayton, and V. C. Radeloff. 2016. The relative impacts of vegetation, topography and spatial arrangement on building loss to wildfires in case studies of California and Colorado. Landscape Ecology 31(2):415-430. http://dx.doi.org/10.1007/s10980-015-0257-6

Bar-Massada, A., V. C. Radeloff, and S. I. Stewart. 2014. Biotic and abiotic effects of human settlements in the wildland-urban interface. BioScience 64:429-437. http://dx.doi.org/10.1093/ $\underline{\text { biosci/biu039 }}$

Bar-Massada, A., A. D. Syphard, S. I. Stewart, and V. C. Radeloff. 2012. Wildfire ignition-distribution modelling: a comparative study in the Huron-Manistee National Forest, Michigan, USA. International Journal of Wildland Fire 22(2):174-183. http://dx. doi.org/10.1071/WF11178

Bhandary, U., and B. Muller. 2009. Land use planning and wildfire risk mitigation: an analysis of wildfire-burned subdivisions using high-resolution remote sensing imagery and GIS data. Journal of Environmental Planning and Management 52 (7):939-955. http://dx.doi.org/10.1080/09640560903181147

Bond, W. J., and J. E. Keeley. 2005. Fire as a global "herbivore": the ecology and evolution of flammable ecosystems. Trends in Ecology \& Evolution 20(7):387-394. http://dx.doi.org/10.1016/j. $\underline{\text { tree.2005.04.025 }}$

Butsic, V., A. D. Syphard, J. E. Keeley, and A. Bar-Massada. 2016. Modeling the impact of private land conservation on wildfire risk in San Diego County, CA. Landscape and Urban Planning, in press.

Buxton, M., R. Haynes, D. Mercer, and A. Butt. 2011. Vulnerability to bushfire risk at Melbourne's urban fringe: the failure of regulatory land use planning. Geographical Research 49 (1):1-12. http://dx.doi.org/10.1111/j.1745-5871.2010.00670.x

Cabeza, M., and A. Moilanen. 2001. Design of reserve networks and the persistence of biodiversity. Trends in Ecology \& Evolution 16(5):242-248. http://dx.doi.org/10.1016/s0169-5347(01)02125-5

Carrión-Flores, C., and E. G. Irwin. 2010. Identifying spatial interactions in the presence of spatial error autocorrelation: an application to land use spillovers. Resource and Energy Economics 32(2):135-153. http://dx.doi.org/10.1016/j.reseneeco.2009.11.009

Carwardine, J., K. A. Wilson, G. Ceballos, P. R. Ehrlich, R. Naidoo, T. Iwamura, S. A. Hajkowicz, and H. P. Possingham. 2008. Cost-effective priorities for global mammal conservation. Proceedings of the National Academy of Sciences 105 (32):11446-11450. http://dx.doi.org/10.1073/pnas.0707157105
Conlisk, E., A. D. Syphard, J. Franklin, and H. M. Regan. 2015. Predicting the impact of fire on a vulnerable multi-species community using a dynamic vegetation model. Ecological Modelling 301:27-39. http://dx.doi.org/10.1016/j.ecolmodel.2015.02.004

Costanza, R., B. Fisher, K. Mulder, S. Liu, and T. Christopher. 2007. Biodiversity and ecosystem services: a multi-scale empirical study of the relationship between species richness and net primary production. Ecological Economics 61(2):478-491. http://dx.doi. org/10.1016/j.ecolecon.2006.03.021

Daniels, T., and M. Lapping. 2005. Land preservation: an essential ingredient in smart growth. Journal of Planning Literature 19(3):316-329. http://dx.doi.org/10.1177/0885412204271379

Driscoll, D. A., M. Bode, R. A. Bradstock, D. A. Keith, T. D. Penman, and O. F. Price. 2016. Resolving future fire management conflicts using multicriteria decision making. Conservation Biology 30(1):196-205. http://dx.doi.org/10.1111/cobi.12580

Driscoll, D. A., D. B. Lindenmayer, A. F. Bennett, M. Bode, R. A. Bradstock, G. J. Cary, M. F. Clarke, N. Dexter, R. Fensham, G. Friend, M. Gill, S. James, G. Kay, D. A. Keith, C. MacGregor, J. Russell-Smith, D. Salt, J. E. M. Watson, R. J. Williams, and A. York. 2010. Fire management for biodiversity conservation: key research questions and our capacity to answer them. Biological Conservation 143(9):1928-1939. http://dx.doi.org/10.1016/j. biocon.2010.05.026

Elith, J., S. J. Phillips, T. Hastie, M. Dudík, Y. E. Chee, and C. J. Yates. 2011. A statistical explanation of MaxEnt for ecologists. Diversity and Distributions 17(1):43-57. http://dx.doi.org/10.1111/ j.1472-4642.2010.00725.X

Fahrig, L. 2003. Effects of habitat fragmentation on biodiversity. Annual Review of Ecology, Evolution, and Systematics 34:487-515. http://dx.doi.org/10.1146/annurev.ecolsys.34.011802.132419

Fattorini, S., and G. Strona. 2016. Human population density and tenebrionid richness covary in Mediterranean islands. Web Ecology 16(1):63-65. http://dx.doi.org/10.5194/we-16-63-2016

Folke, C., S. Carpenter, B. Walker, M. Scheffer, T. Elmqvist, L. Gunderson, and C. S. Holling. 2004. Regime shifts, resilience, and biodiversity in ecosystem management. Annual Review of Ecology, Evolution, and Systematics 35:557-581. http://dx.doi. org/10.1146/annurev.ecolsys.35.021103.105711

Franklin, J, K. E. Wejnert, S. A. Hathaway, C. J. Rochester, and R. N. Fisher. 2009. Effect of species rarity on the accuracy of species distribution models for reptiles and amphibians in southern California. Diversity and Distributions 15:167-177. http://dx.doi.org/10.1111/j.1472-4642.2008.00536.x

Gerber, J.-D., and A. R. Rissman. 2012. Land-conservation strategies: the dynamic relationship between acquisition and landuse planning. Environment and Planning A 44(8):1836-1855. http://dx.doi.org/10.1068/a44395

Giljohann, K. M., M. A. McCarthy, L. T. Kelly, and T. J. Regan. 2015. Choice of biodiversity index drives optimal fire management decisions. Ecological Applications 25(1):264-277. http://dx.doi.org/10.1890/14-0257.1

Gill, A. M., S. L. Stephens, and G. J. Cary. 2013. The worldwide "wildfire" problem. Ecological Applications 23(2):438-454. http:// dx.doi.org/10.1890/10-2213.1 
Gustafson, E. J. 1998. Quantifying landscape spatial pattern: What is the state of the art? Ecosystems 1:143-156. http://dx.doi. org/10.1007/s100219900011

Hansen, A. J., R. L. Knight, J. M. Marzluff, S. Powell, K. Brown, P. H. Gude, and K. Jones. 2005. Effects of exurban development on biodiversity: patterns, mechanisms, and research needs. Ecological Applications 15(6):1893-1905. http://dx.doi. org/10.1890/05-5221

Irwin, E. G., K. P. Bell, N. E. Bockstael, D. A. Newburn, M. D. Partridge, and J. Wu. 2009. The economics of urban-rural space. Annual Review of Resource Economics 1(1):435-459. http://dx.doi. org/10.1146/annurev.resource.050708.144253

Keeley, J. E. 2005. Fire history of the San Francisco East Bay region and implications for landscape patterns. International Journal of Wildland Fire 14(3):285-296. http://dx.doi.org/10.1071/ $\underline{\mathrm{WF} 05003}$

Keeley, J. E. 2006. South coast bioregion. Pages 350-390 in N. G. Sugihari, J. W. van Wagtendonk, K. E. Shaffer, J. Fites-Kaufman, and A. E. Thode, editors. Fire in California's ecosystems. University of California Press, Berkeley, California, USA. http:// dx.doi.org/10.1525/california/9780520246058.003.0015

Keeley, J. E., G. H. Aplet, N. L. Christensen, S. G. Conard, E. A. Johnson, P. N. Omi, D. L. Peterson, and T. W. Swetnam. 2009. Ecological foundations for fire management in North American forest and shrubland ecosystems. USDA Forest Service, Pacific Northwest Research Station, Portland, Oregon, USA.

Keeley, J. E., and T. J. Brennan. 2012. Fire-driven alien invasion in a fire-adapted ecosystem. Oecologia 169(4):1043-1052. http:// dx.doi.org/10.1007/s00442-012-2253-8

Keeley, J. E., and F. W. Davis. 2007. Chaparral. Pages 339-366 in M. G. Barbour, T. Keeler-Wolf, and A. A. Schoenherr, editors. Terrestrial vegetation of California. Third edition. University of California Press, Berkeley, California, USA.

Keeley, J. E., C. J. Fotheringham, and M. Morais. 1999. Reexamining fire suppression impacts on brushland fire regimes. Science 284:1829-1832. http://dx.doi.org/10.1126/science.284.5421.1829

Keeley, J. E., J. G. Pausas, P. W. Rundel, W. J. Bond, and R. A. Bradstock. 2011. Fire as an evolutionary pressure shaping plant traits. Trends in Plant Science 16:406-411. http://dx.doi. org/10.1016/j.tplants.2011.04.002

Lampin-Maillet, C., M. Long-Fournel, A. Ganteaume, M. Jappiot, and J. P. Ferrier. 2011. Land cover analysis in wildlandurban interfaces according to wildfire risk: a case study in the South of France. Forest Ecology and Management 261 (12):2200-2213. http://dx.doi.org/10.1016/j.foreco.2010.11.022

Land Trust Alliance. 2015. Land Trust Alliance: together, conserving the places you love. Land Trust Alliance, Washington, D.C., USA. [online] URL: http://www.landtrustalliance.org

Lippitt, C. L., D. A. Stow, J. F. O’Leary, and J. Franklin. 2012. Influence of short-interval fire occurrence on post-fire recovery of fire-prone shrublands in California, USA. International Journal of Wildland Fire 22(2):184-193. http://dx.doi.org/10.1071/ $\underline{\mathrm{wf} 10099}$
Luck, G. W. 2007. A review of the relationships between human population density and biodiversity. Biological Reviews 82 (4):607-645. http://dx.doi.org/10.1111/j.1469-185x.2007.00028.x

Margules, C., A. J. Higgs, and R. W. Rafe. 1982. Modern biogeographic theory: Are there any lessons for nature reserve design? Biological Conservation 24(2):115-128. http://dx.doi. org/10.1016/0006-3207(82)90063-5

Margules, C. R., and R. L. Pressey. 2000. Systematic conservation planning. Nature 405(6783):243-253. http://dx.doi.org/10.1038/35012251

McGarigal, K., S. A. Cushman, and E. Ene. 2012. FRAGSTATS v4: Spatial pattern analysis program for categorical maps. Computer software program. University of Massachusetts, Amherst, Massachusetts, USA. [online] URL: http://www.umass. edu/landeco/research/fragstats/fragstats.html

Messner, S., S. C. Miranda, E. Young, and N. Hedge. 2011. Climate change-related impacts in the San Diego region by 2050. Climatic Change 109(S1):505-531. http://dx.doi.org/10.1007/ s10584-011-0316-1

Miles, S. R., and C. B. Goudey. 1997. Ecological subregions of California: section and subsection descriptions. R5-EM-TP-005. U.S. Forest Service, Pacific Southwest Region, San Francisco, California, USA.

Moilanen, A., H. P. Possingham, and S. Polasky. 2009. A mathematical classification of conservation prioritization problems. Pages 28-42 in A Moilanen, K. A. Wilosn, and H. P. Possingham, editors. Spatial conservation prioritization: quantitative methods \& computational tools. Oxford University Press, Oxford, UK.

Moritz, M. A., E. Batllori, R. A. Bradstock, A. M. Gill, J. Handmer, P. F. Hessburg, J. Leonard, S. McCaffrey, D. C. Odion, T. Schoennagel, and A. D. Syphard. 2014. Learning to coexist with wildfire. Nature 515(7525):58-66. http://dx.doi.org/10.1038/ $\underline{\text { nature } 13946}$

Moritz, M. A., T. J. Moody, M. A. Krawchuk, M. Hughes, and A. Hall. 2010. Spatial variation in extreme winds predicts large wildfire locations in chaparral ecosystems. Geophysical Research Letters 37(4). http://dx.doi.org/10.1029/2009g1041735

Moritz, M. A., M.-A. Parisien, E. Batllori, M. A. Krawchuk, J. Van Dorn, D. J. Ganz, and K. Hayhoe. 2012. Climate change and disruptions to global fire activity. Ecosphere 3(6):1-22. http://dx. doi.org/10.1890/es11-00345.1

Morrison, D. A., R. T. Buckney, B. J. Bewick, and G. J. Cary. 1996. Conservation conflicts over burning bush in south-eastern Australia. Biological Conservation 76(2):167-175. http://dx.doi. org/10.1016/0006-3207(95)00098-4

Naeem, S., K. Håkansson, J. H. Lawton, M. J. Crawley, and L. J. Thompson. 1996. Biodiversity and plant productivity in a model assemblage of plant species. Oikos 76(2):259-264. http://dx.doi. org/10.2307/3546198

Newburn, D., S. Reed, P. Berck, and A. Merenlender. 2005. Economics and land-use change in prioritizing private land conservation. Conservation Biology 19(5):1411-1420. http://dx. doi.org/10.1111/j.1523-1739.2005.00199.x 
Oberbauer, T., F. Sproul, J. Dunn, and L. Woolley. 2012. 2012 Vegetation, San Diego County, California. AECOM, Los Angeles, California, USA.

Odell, E. A., D. M. Theobald, and R. L. Knight. 2003. Incorporating ecology into land use planning: the songbirds' case for clustered development. Journal of the American Planning Association 69(1):72-82. http://dx.doi.org/10.1080/01944360308976294

Ohlson, D. W., T. M. Berry, R. W. Gray, B. A. Blackwell, and B. C. Hawkes. 2006. Multi-attribute evaluation of landscape-level fuel management to reduce wildfire risk. Forest Policy and Economics 8(8):824-837. http://dx.doi.org/10.1016/j.forpol.2005.01.001

Phillips, S. J., R. P. Anderson, and R. E. Schapire. 2006. Maximum entropy modeling of species geographic distributions. Ecological Modelling 190(3-4):231-259. http://dx.doi.org/10.1016/j. ecolmodel.2005.03.026

Pollak, D. 2001. The future of habitat conservation? The NCCP experience in southern California. Report No. CRB-01-009. California State Library-California Research Bureau, Sacramento, California, USA.

Principe, Z., J. B. MacKenzie, B. Cohen, J. M. Randall, W. Tippets, T. Smith, and S. A. Morrison. 2013.50-Year climate scenarios and plant species distribution forecasts for setting conservation priorities in Southwestern California v. 1. The Nature Conservancy of California, San Francisco, California, USA.

Pyne, S. J., P. L. Andrews, and R. D. Laven. 1996. Introduction to wildland fire. Wiley, New York, New York, USA.

Regan, H. M., L. A. Hierl, J. Franklin, D. H. Deutschman, H. L. Schmalbach, C. S. Winchell, and B. S. Johnson. 2008. Species prioritization for monitoring and management in regional multiple species conservation plans. Diversity and Distributions 14:462-471. http://dx.doi.org/10.1111/j.1472-4642.2007.00447.x

Rochester, C. J., C. S. Brehme, D. R.Clark, D. C. Stokes, S. A. Hathaway, and R. N. Fisher. 2010. Reptile and amphibian responses to large-scale wildfires in southern California. Journal of Herpetology 44:333-351. http://dx.doi.org/10.1670/08-143.1

Safford, H., K. Van de Water, and D. Schmidt. 2011. California fire return interval departure (FRID) map, 2010 version. U.S. Forest Service, Pacific Southwest Region and The Nature Conservancy of California, San Francisco, California, USA.

Safford, H. D., and K. M. Van de Water. 2014. Using fire return interval departure (FRID) analysis to map spatial and temporal changes in fire frequency on national forest lands in California. Research Paper PSW-RP-266. U.S. Forest Service, Pacific Southwest Research Station, Albany, California, USA. http://dx. doi.org/10.2737/psw-rp-266

San Diego County. 2011. San Diego County general plan. San Diego County, California, USA.

San Diego County. 2015. About the multi species conservation program. San Diego County, California, USA. [online] URL: http://www.sandiegocounty.gov/content/sdc/pds/mscp/overview.html

Stephens, S. L., J. D. McIver, R. E. J. Boerner, C. J. Fettig, J. B. Fontaine, B. R. Hartsough, P. L. Kennedy, and D. W. Schwilk. 2012. The effects of forest fuel-reduction treatments in the United
States. BioScience 62(6):549-560. http://dx.doi.org/10.1525/ bio.2012.62.6.6

Syphard, A. D., A. Bar Massada, V. Butsic, and J. E. Keeley. 2013. Land use planning and wildfire: development policies influence future probability of housing loss. PLOS ONE 8(8):e71708. http:// dx.doi.org/10.1371/journal.pone.0071708

Syphard, A. D., K. C. Clarke, and J. Franklin. 2007b. Simulating fire frequency and urban growth in southern California coastal shrublands, USA. Landscape Ecology 22(3):431-445. http://dx. doi.org/10.1007/s10980-006-9025-y

Syphard, A. D., and J. E. Keeley. 2015. Location, timing and extent of wildfire vary by cause of ignition. International Journal of Wildland Fire 24(1):37-47. http://dx.doi.org/10.1071/wf14024

Syphard, A. D., J. E. Keeley, A. Bar Massada, T. J. Brennan, and V. C. Radeloff. 2012. Housing arrangement and location determine the likelihood of housing loss due to wildfire. PLoS ONE 7(3):e33954. \http://dx.doi.org/10.1371/journal.pone.0033954

Syphard, A. D., V. C. Radeloff, T. J. Hawbaker, and S. I. Stewart. 2009. Conservation threats due to human-caused increases in fire frequency in Mediterranean-climate ecosystems. Conservation Biology 23:758-769. http://dx.doi.org/10.1111/j.1523-1739.2009.01223. $\underline{\mathrm{X}}$

Syphard, A. D., V. C. Radeloff, J. E. Keeley, T. J. Hawbaker, M. K. Clayton, S. I. Stewart, and R. B. Hammer. 2007a. Human influence on California fire regimes. Ecological Applications 17 (5):1388-1402. http://dx.doi.org/10.1890/06-1128.1

Taylor, R. S., S. J. Watson, A. F. Bennett, and M. F. Clarke. 2013. Which fire management strategies benefit biodiversity? A landscape-perspective case study using birds in mallee ecosystems of south-eastern Australia. Biological Conservation 159:248-256. http://dx.doi.org/10.1016/j.biocon.2012.12.005

Turner, M. G. 1989. Landscape ecology: the effect of pattern on process. Annual Review of Ecology and Systematics 20:171-197. http://dx.doi.org/10.1146/annurev.es.20.110189.001131

Underwood, J. G., J. Francis, and L. R. Gerber. 2011. Incorporating biodiversity conservation and recreational wildlife values into smart growth land use planning. Landscape and Urban Planning 100(1-2):136-143. http://dx.doi.org/10.1016/j. landurbplan.2010.11.014

Viedma, O., N. Moity, and J. M. Moreno. 2015. Changes in landscape fire-hazard during the second half of the 20th century: agriculture abandonment and the changing role of driving factors. Agriculture, Ecosystems \& Environment 207:126-140. http://dx. doi.org/10.1016/j.agee.2015.04.011

Wilson, K. A, M. F. McBride, M. Bode, and H. P. Possingham. 2006. Prioritizing global conservation efforts. Nature 440 (7082):337-340. http://dx.doi.org/10.1038/nature04366

Zedler, P. H., C. R. Gautier, and G. S. McMaster. 1983. Vegetation change in response to extreme events: the effect of a short interval between fires in California chaparral and coastal scrub. Ecology 64:809-818. http://dx.doi.org/10.2307/1937204 